DOI: $10.15421 / 4220006$

УДК 539.3

\author{
P. М. Мартиняк ${ }^{1}$, д-р фріз.-мат. наук, \\ О. В. Приходько², канд. фріз.-мат. наук
}

\title{
ЗАДАЧА ПРО ВДАВЛЮВАННЯ БЛИЗЬКОГО ДО ПЛОСКОГО ШТАМПУ В ПРУЖНИЙ ШОРСТКИЙ ПІВПРОСТІР
}

Отримано числовий розв'язок для статичної просторової контактної задачі про вдавлювання близького до плоского штампу з заокругленими краями в пружний шорсткий півпростір. Шорсткість в цій задачі було враховано шляхом введення в вирази відносних пружних переміщень взаємодіючих тіл нелінійних доданків, що характеризують зім'яття поверхневих мікронерівностей. Проаналізовано розподіл нормальних контактних напружень, залежність радіуса площинки контакту та максимального тиску від навантаження.

Ключові слова: пружне тіло; шорстка поверхня; контактна задача; числовий розв'язок; ітераційний процес.

Вступ. Для забезпечення контактної міцності сучасних елементів машин і конструкцій некласичної конфрігурації та оптимізації їх функціональних характеристик важливого значення набувають дослідження контактних задач для тіл, форма яких описується широким спектром функцій. Зараз такі дослідження ведуться, зокрема, для тіл 3 текстурованими поверхнями $[10,13,14]$ та складнопрофрільних тіл [11, 12]. Використання нелінійних інтегральних рівнянь для моделювання контактних взаємодій пружних тіл [1, 3, 5-7] дозволяє розробляти ефективні ітераційні методи розв'язання контактних задач для структур складної форми і дає можливість позбавитись від основної проблеми реалізації варіаційних методів, яка полягає в необхідності розглядати достатньо складні задачі нелінійного програмування. Основні та найвідоміші з таких рівнянь $[6,7] \epsilon$ операторними рівняннями першого роду, для яких пошук ефективних ітераційних процесів отримання наближеного розв'язку $є$ важким завданням. Нелінійні інтегральні рівняння, використані в [1, 3], які $€$ операторними рівняннями другого роду, дозволяють враховувати шорсткість поверхонь взаємодіючих тіл і можуть бути використані для розробки ефективного числового алгоритму розв'язування контактних задач, заснованих на побудові простих для програмної реалізації збіжних ітераційних процесів. Метою даної статті $€$ розробка такого алгоритму та його використання для розв'язування просторової осесиметричної задачі про вдавлювання близького до плоского штампу з заокругленими краями в пружний шорсткий півпростір.

(ㄱ Р. М. Мартиняк, О. В. Приходько, 2020 
Інтегральне рівняння контактної задачі. Розглянемо загальну постановку статичної просторової контактної задачі про взаємодію двох пружних тіл при відсутності тертя між ними і невідомій поверхні контакту. Будемо вважати, що тіла мають шорсткі поверхні і можуть бути апроксимовані пружними півпросторами. Задача зводиться до розв'язання нелінійного інтегрального рівняння [3]

$$
p(s)=h(p(s)-E(f(p(s))+A(p)(s)-g(s))) ; \quad s \in \Omega,
$$

де $p(s)$ - невідома функція, що відшукується в просторі $L_{2}(\Omega)$ [9], $є$ розподілом контактних тисків в заданій плоскій обмеженій області $\Omega$, яка містить в собі невідому площинку контакту і розташована в спільній для тіл дотичній площині $G$, що проходить через точку їх початкового дотику; $E$ - довільна додатна константа; $A$ - лінійний обмежений інтегральний оператор впливу $\left(A: L_{2}(\Omega) \rightarrow L_{2}(\Omega)\right) \quad$ задається співвідношеннями

$$
A(p)(s)=\int_{\Omega} K(s, t) p(t) d t, \quad s \in \Omega .
$$

Тут $K(s, t)=\frac{c}{|s-t|} ;|s-t|-$ відстань між точками $s$ і $t$ площини $G$; $c=\left(1-v_{1}^{2}\right) \cdot\left(\pi E_{1}\right)^{-1}+\left(1-v_{2}^{2}\right) \cdot\left(\pi E_{2}\right)^{-1} ; v_{1}, v_{2}, E_{1}, E_{2}-$ коефріцієнти Пуассона і модулі Юнга взаємодіючих тіл [1].

Функції $h(x)$ і $g(s)$ в правій частині рівняння (1) задаються співвідношеннями:

$$
h(x)=\frac{1}{2}(x+|x|) \quad \forall x \in R ; \quad g(s)=-\delta_{0}(s)+\Delta \quad \forall s \in \Omega,
$$

де $R$ - множина дійсних чисел; $\delta_{0}(s)$ - зазор між тілами в момент їхнього початкового дотику, виміряний в напрямку нормалі до площини $G ; \Delta>0$ - зближення тіл в напрямку тієї ж нормалі.

Вираз $f(p(s))$ в рівнянні (1) задає зім'яття поверхневих шарів тіл і враховує деформації мікронерівностей, які утворюють шорсткість [3]. Будемо вважати, що функція $f(x)$ в цьому виразі $€$ неперервною, строго зростаючою, непарною і необмеженою на всій дійсній числовій прямій [3]. Окрім цього припустимо, що $f(p(s)) \in L_{2}(\Omega)$ для кожної функції $p(s) \in L_{2}(\Omega)$.

Отримання точного або наближеного розв'язку інтегрального рівняння (1) аналітичними методами є занадто складним, тому що плоска поверхня контакту тіл є заздалегідь невідомою і може мати дуже 
складну конфігурацію. Тому для розв'язання цього рівняння доцільно використовувати числові методи, які засновані на його дискретизації.

Дискретизація інтегрального рівняння. Замінивши у рівнянні (1) лінійний обмежений оператор $A: L_{2}(\Omega) \rightarrow L_{2}(\Omega)$ виду (2) на близький до нього лінійний обмежений оператор $A_{n}: L_{2}(\Omega) \rightarrow L_{2}(\Omega)$, а елемент $g(s) \in L_{2}(\Omega)$ виду (3) на близький до нього елемент $g_{n}(s) \in L_{2}(\Omega)$, отримаємо рівняння

$$
p(s)=h\left(p(s)-E\left(f(p(s))+A_{n}(p)(s)-g_{n}(s)\right)\right), \quad s \in \Omega .
$$

Апроксимуючий оператор $A_{n}$ i апроксимуючий елемент $g_{n}(s)$ побудуємо так, щоб це рівняння мало розв'язок в класі визначених на $\Omega$ кусково-постійних функцій. Для цього введемо на площині $G$ декартову систему координат з центром в точці початкового дотику тіл і задамо область $\Omega$ у вигляді відкритого квадрату площі $d$, обмеженого відрізками прямих, паралельних координатним осям цієї системи. Далі для натурального числа $n$ розіб'ємо область $\Omega$ на $n^{2}$ квадратних областей $\omega_{1}^{n}, \omega_{2}^{n}, \ldots, \omega_{n^{2}}^{n}$ рівної площі, які не перетинаються та орієнтовані подібно квадрату $\Omega$. Позначивши символом $s_{i}^{n}$ центр квадрата $\omega_{i}^{n}$, задамо оператор $A_{n}: L_{2}(\Omega) \rightarrow L_{2}(\Omega)$ та елемент $g_{n}(s) \in L_{2}(\Omega)$ наступними співвідношеннями:

$$
\left\{\begin{array}{l}
A_{n}(p)(s)=\int_{\Omega} K_{n}(s, t) p(t) d t ; \\
K_{n}(s, t)=\alpha_{i j}^{(n)}, \quad \text { якщо } \quad s \in \omega_{i}^{n} \quad i \quad t \in \omega_{j}^{n} ; \\
\alpha_{i j}^{(n)}=\left\{\begin{array}{l}
\frac{c}{\left|s_{i}^{n}-s_{j}^{n}\right|}, \quad \text { якщо } \quad i \neq j ; \\
\frac{c n^{2}}{d} \int_{\omega_{i}^{n} \mid} \frac{d t}{\left|s_{i}^{n}-t\right|}, \quad \text { якщо } i=j ; \\
g_{n}(s)=g\left(s_{i}^{n}\right), \quad \text { якщоо } s \in \omega_{i}^{n} .
\end{array}\right.
\end{array}\right.
$$

В [2] доведено, що апроксимуючі послідовності $\left\{A_{n}\right\},\left\{g_{n}\right\}$, побудовані за правилом (5), збігаються до оператора $A: L_{2}(\Omega) \rightarrow L_{2}(\Omega)$ виду (2) і до елемента $g(s) \in L_{2}(\Omega)$ відповідно, якщо фуннкція $g(s)$ визначена і 
неперервна на замиканні області $\Omega$. Неважко переконатись, що для оператора $A_{n}$ і елемента $g_{n}$, заданих рівностями (5), інтегральне рівняння (4) зводиться до наступної системи $m$ скалярних рівнянь $3 \mathrm{~m}$ невідомими:

$$
x_{i}=h\left(x_{i}-E\left(f\left(x_{i}\right)+\sum_{j=1}^{m} b_{i j} x_{j}-g_{i}\right)\right), \quad i=\overline{1, m} .
$$

Зв'язок між невідомими $x_{1}, x_{2}, \ldots, x_{m}$ та функцією $p(s)$, яка задовольняє рівнянню (4), такий, що $p(s)=x_{i}$ для всіх $s \in \omega_{i}^{n}$. Параметри $m, b_{i j}$ та $g_{i}$ визначаються співвідношеннями:

$$
m=n^{2} ; \quad b_{i j}=\alpha_{i j}^{(n)} \frac{d}{n^{2}}, \quad g_{i}=g\left(s_{i}^{n}\right), \quad(i, j=\overline{1, m}) .
$$

Отже, числове розв'язування інтегрального рівняння (1) зводиться до знаходження розв'язку системи скалярних рівнянь (6), для якої числові параметри $m, b_{i j}$ та $g_{i}$ задаються рівностями (7).

Ітераційні процеси для розв'язання дискретизованого рівняння. Розв'язок системи нелінійних рівнянь (6) можна отримати, використовуючи ітераційний процес

$$
\left\{\begin{array}{l}
x_{i}^{(0)}=0 \quad \forall i=\overline{1, m} \\
x_{i}^{(k)}=h\left(x_{i}^{(k-1)}-E\left(f\left(x_{i}^{(k-1)}\right)+\sum_{j=1}^{m} b_{i j} x_{j}^{(k-1)}-g_{i}\right)\right), i=\overline{1, m} ; k=1,2, \ldots
\end{array}\right.
$$

Для забезпечення збіжності цього процесу необхідно параметр $E$, який входить в праві частини рівностей (8), вибирати наступним чином:

$$
0<E \leq\left(L+\max _{1 \leq i \leq m}\left(\sum_{j=1}^{m}\left|b_{i j}\right|\right)\right)^{-1},
$$

де невід'ємне число $L$ залежить від властивостей функції $f(x)$, за допомогою якої враховується шорсткість поверхонь взаємодіючих тіл.

Збіжність цього ітераційного процесу доведена в [4].

Шорсткість поверхні враховується за допомогою степеневого закону [5]

$$
f(x)=\alpha \cdot x^{K} \quad \forall x \in[0 ;+\infty), \quad 0<K \leq 1 .
$$


Числові результати. За допомогою запропонованого алгоритму був отриманий числовий розв'язок просторової осесиметричної контактної задачі про вдавлювання силою $P$ близького до плоского штампу 3 заокругленими краями в пружний шорсткий півпростір. Форма штампу задана рівнянням:

$$
z=R-\sqrt[N]{R^{N}-\sqrt{\left(x^{2}+y^{2}\right)^{N}}},
$$

де $\boldsymbol{R}=\Omega_{1 \wedge \boldsymbol{n}}, \quad 2 \leq N \leq 8$. Обчислення проведено для півпростору 3 пружними сталими $v_{2}=0,3$ і $E_{2}=210000$ МПа та абсолютно жорсткого штампу $\left(E_{1}=+\infty\right)$. Функція $f(x)$, за допомогою якої враховувалась шорсткість, задана співвідношенням (10), в якому $K=0,5$, $\alpha=3 \cdot 10^{-10,5}$ м / (Па $)^{-0,5}$ [8].

Числовий розв'язок задачі отримано на сітці, яка складається 3 $51 \times 51=2601$ квадратного граничного елементу, площа кожного з яких дорівнює $10^{-8} \mathrm{M}^{2}$ для $N=2 ; 25 \cdot 10^{-8} \mathrm{M}^{2}$ для $N=4$ та $156,25 \cdot 10^{-8} \mathrm{M}^{2}$ для $N=8$. Числові параметри $b_{i j}$ та $g_{i}$, які входять в систему (6), обчислено за формулами (5), (7). Для отримання результатів використовувався ітераційний процес (8), в якому значення $E$ вибиралось найбільшим з усіх можливих значень, що задані співвідношенням (9) при $L=f(a) / a, a=1500$ МПа .

Отримані результати наведені на рис. 1 - рис. 5 , де пунктирна лінія відповідає розв'язку контактної задачі без врахування шорсткості, а суцільна лінія - розв'язку цієї задачі з урахуванням деформації поверхневих мікронерівностей тіл.

На рис. 1 - рис. 3 зображено форму штампу та розподіл контактних тисків для трьох значень навантажень $P_{1}=5 \kappa H, \quad P_{2}=10 \kappa H$, $P_{3}=15 \kappa H$ при трьох значеннях параметра $N$ у формі штампа (11): $N=2, N=4$ i $N=8$.

Криві на рис. 1, що відповідають $N=2$, свідчать про те, що врахування шорсткості поверхонь тіл в контактній задачі, яка розглядається, призводить до помітного зростання радіуса зони контакту і до зменшення максимального значення контактних тисків у порівнянні з випадком без врахування шорсткості. Відмітимо, що при врахуванні шорсткості найбільше значення тисків $p_{\max }$, яке досягається в центрі ділянки контакту, помітно знижується у порівнянні з випадком без врахування шорсткості, зокрема на $13,9 \%$ при $P_{1}=5 \kappa H$ та на $8,3 \%$ при $P_{3}=15 \kappa H$. Зростання радіусу зони контакту, яке є наслідком урахування шорсткості поверхонь тіл, становить $20,8 \%$ при $P_{1}=5 \kappa H$ та $16,9 \%$ при $P_{3}=15 \kappa H$.

3 рис. 2 видно, що контактні тиски досягають максимуму на периферії ділянки контакту, а в її центрі мають локальний мінімум. При 
врахуванні шорсткості найбільше значення тисків $p_{\max }$ знижується у порівнянні 3 випадком без врахування шорсткості на 14,9\% при $P_{1}=5 \kappa H$ та на $9,5 \%$ при $P_{3}=15 \kappa H$. Зростання радіусу зони контакту становить $14,7 \%$ при $P_{1}=5 \kappa H$ та $7,4 \%$ при $P_{3}=15 \kappa H$.

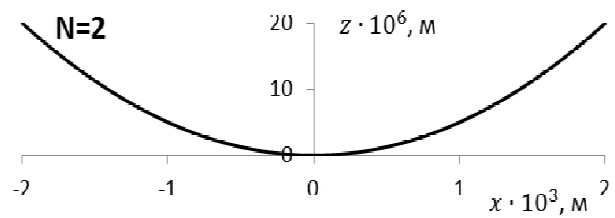

a)

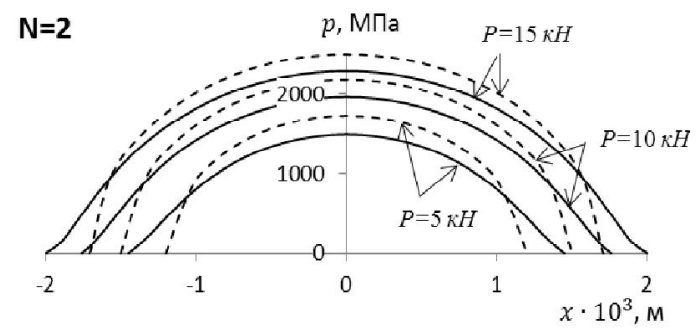

б)

Рис. 1 - Форма штампу (а) та розподіл контактних тисків (б) при $N=2$

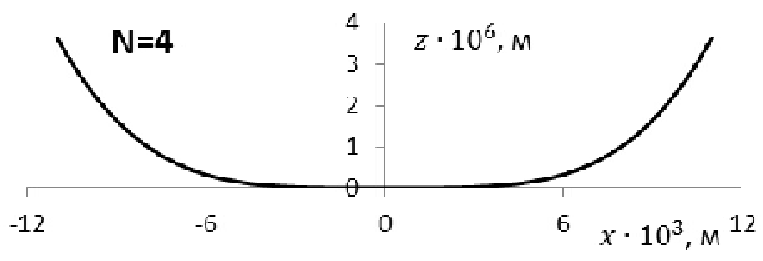

a)

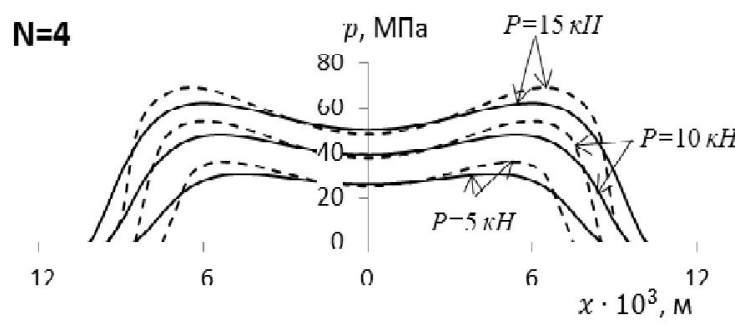

б)

Рис. 2 - Форма штампу (а) та розподіл контактних тисків (б) при $N=4$ 


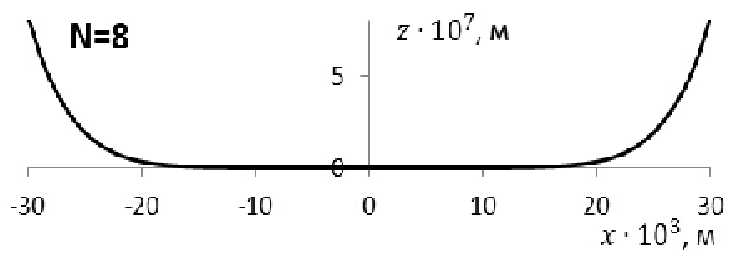

a)

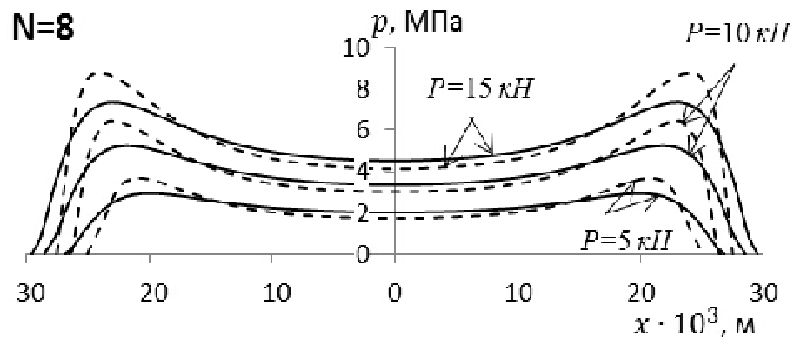

б)

Рис. 3 - Форма штампу (а) та розподіл контактних тисків (б) при $N=8$

Криві на рис. 3, що відповідають $N=8$, свідчать про те, що при врахуванні шорсткості найбільше значення тисків $p_{\max }$ знижується у порівнянні з випадком без врахування шорсткості на 20,5\% при $P_{1}=5 \kappa H$ та на $16,1 \%$ при $P_{3}=15 \kappa H$. Зростання радіусу зони контакту становить 7,2\% при $P_{1}=5 \kappa H$ та $7,3 \%$ при $P_{3}=15 \kappa H$.

Отже, найбільше зростання значення тисків $p_{\max }$ при врахуванні шорсткості відбувається при формі штампу (11), де $N=8$.

На рис. 4 зображено залежність радіуса площинки контакту від навантаження для різних $N$.

Найбільше зростання радіусу зони контакту при врахуванні шорсткості сягає $20,8 \%$ для $N=2$.

На рис. 5 подано залежність значення максимального контактного тиску від навантаження.

Аналіз результатів показує, що чим більше навантаження, тим більш помітне відхилення $p_{\max }$ без врахування шорсткості від $p_{\max } 3$ їі урахуванням. Найбільше відхилення $p_{\max }$ при врахуванні шорсткості сягає $20,5 \%$ для $N=8$. 


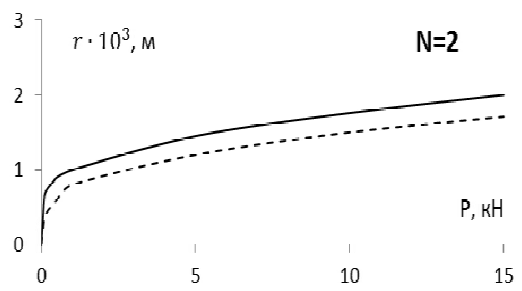

a) $N=2$

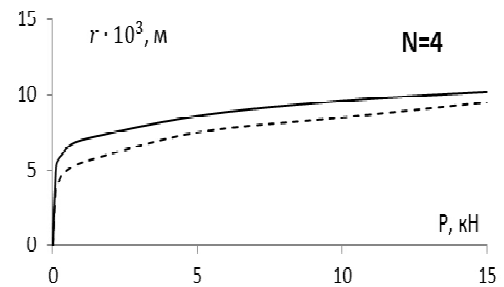

б) $N=4$

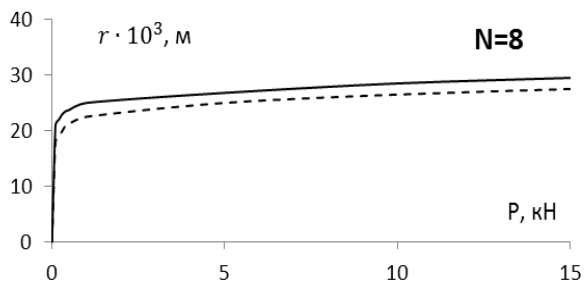

B) $N=8$

Рис. 4 - Залежність радіуса площинки контакту від навантаження

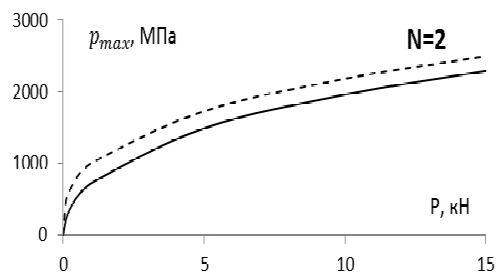

a) $N=2$

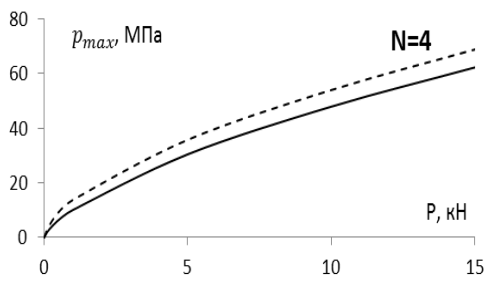

б) $N=4$

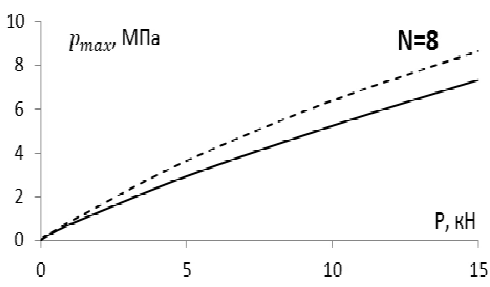

B) $N=8$

Рис. 5 - Залежність значення максимального контактного тиску від навантаження 
Висновок. Запропонований алгоритм дозволяє отримувати числовий розв'язок просторової статичної контактної задачі про взаємодію пружних шорстких тіл при відсутності тертя між ними і заздалегідь невідомій площинці контакту. Отримано розв'язок задачі про вдавлювання близького до плоского штампу з заокругленими краями в пружний шорсткий півпростір. Аналіз одержаних результатів свідчить про те, що врахування шорсткості поверхні може призводити до помітного збільшення розмірів зони контакту і до істотної зміни в розподілі нормальних контактних напружень.

\section{БІБЛІОГРАФІЧНІ ПОСИЛАННЯ}

1. Александров А.И. Решение задач контактного взаимодействия упругих тел с использованием нелинейных операторных уравнений. Д.: Ин-т технической механики АН УССР, 1989. 74 с. (Препринт / АН УССР, Ин-т технической механики; 89-2).

2. Александров А.И. Вопросы существования решений некоторых нелинейных интегральных уравнений. Д.: ДГУ, 1991. 48 с.

3. Александров А.И., Грабко Е.В. Теоремы существования решения для контактной задачи о взаимодействии упругих тел, имеющих шероховатые поверхности // Вісник ЗНУ. Сер.: Фізико-математичні науки. 2010. № 1. С. 11-17.

4. Александров А.И., Грабко Е.В. Алгоритм численного решения пространственной контактной задачи о взаимодействии упругих тел, имеющих шероховатые поверхности. // Проблеми обчислювальної механіки і міцності конструкцій. 2011. Вип. 17. С. 23-34.

5. Александров В.М., Пожарский Д.А. Трехмерные контактные задачи при учете трения и нелинейной шероховатости // Прикладная математика и механика. 2004. Т. 68. Вып. 3. С. 516-527.

6. Галанов Б.А. Метод граничных уравнений типа Гаммерштейна для контактных задач теории упругости в случае неизвестных областей контакта // Прикладная математика и механика. 1985. Т. 49. Вып. 5. С. 827-835.

7. Галанов Б.А. Нелинейные граничные уравнения контактных задач теории упругости // Докл. АН СССР. 1987. Т. 296. № 4. С. 812-815.

8. Грабко О.В. Врахування шорсткості поверхонь в задачі про контакт пружних куль // Вісник ЗНУ. Сер.: Фізико-математичні науки. 2011. № 1. С. 14-18. 752 c.

9. Канторович Л.В., Акилов Г.П. Функциональный анализ. М.: Наука, 1984.

10. Козачок О.П., Мартиняк Р.М., Слободян Б.С., Взаємодія тіл з регулярним рельєфом за наявності міжконтактного середовища. Львів: Растр-7, 2018. 200 с.

11. Ткачук Н.Н., Скрипченко Н.Б., Ткачук Н.А., Грабовский А.В. Контактное взаимодействие сложнопрофильных деталей машиностроительных конструкций с учетом локальной податливости поверхностного слоя. Харьков: ФОП Панов А.Н., 2017. 148 c.

12. Ткачук Н.Н.. Ткачук Н.А. Контакт сложнопрофильных тел: связанная задача анализа напряженно-деформированного состояния и геометрического синтеза // Механіка та машинобудування. 2011. № 2. С. 75-86.

13. Goryacheva I.G., Martynyak R.M. Contact problems for textured surfaces involving frictional effects // Proceedings of the Institution of Mechanical Engineers, Part J: Journal of Engineering Tribology. 2014. Vol. 228. No 7. P. 707-716.

14. Goryachev I.G., Malanchuk N.I., Martynyak R.M. Contact interaction of bodies with a periodic relief during partial slip // Journal of Applied Mathematics and Mechanics. 2012. Vol. 76. No 5. P. 621-630. 


\author{
P. М. Мартыняк ${ }^{1}$ д-р фриз.-мат. наук, \\ Е. В. Приходько ${ }^{2}$ канд. фоз.-мат. наук
}

\title{
ЗАДАЧА О ВДАВЛИВАНИИ БЛИЗКОГО К ПЛОСКОМУ ШТАМПА В УПРУГОЕ ШЕРОХОВАТОЕ ПОЛУПРОСТРАНСТВО
}

\begin{abstract}
Получено численное решение для статической пространственной контактной задачи о вдавливании близкого к плоскому штампа с закругленными краями В упругое шероховатое полупространство. Шероховатость в этой задаче учитывалась путем введения в выражения относительных упругих перемещений взаимодействующих тел нелинейных слагаемых, характеризующих смятие поверхностных микронеровностей. Проанализировано распределение нормальных контактных напряжений, зависимость радиуса площадки контакта и максимального давления от нагрузки.
\end{abstract}

Ключевые слова: упругое тело; шероховатая поверхность; контактная задача; численное решение; итерационный процесс.

UDC 539.3

\author{
R. M. Martynyak ${ }^{1}$, Dr. Sci. (Phys.-Math.), \\ O. V. Prykhodko ${ }^{2}$, PhD (Phys.-Math.)
}

\section{THE PROBLEM OF PRESSING A CLOSE TO FLAT STAMP IN AN ELASTIC ROUGH HALF-SPACE}

A numerical solution was obtained for a static spatial contact problem of extruding a close to flat stamp with rounded edges into an elastic rough half-space. The roughness in this problem was taken into account by introducing into the expressions of the relative elastic displacements of interacting bodies of nonlinear terms, which characterize the crushing of surface microirregularities. The distribution of normal contact stresses, the dependence of the radius of the contact plane and the maximum pressure on the load are analyzed.

Keywords: elastic body; rough surface; contact problem; the numerical solution; the iterative process.

The use of the nonlinear integral equations to model the contact interactions of elastic bodies [1, 3, 5-7] allows us to develop effective iterative methods for solving contact problems. Also, the use of such equations makes it possible to get rid of the main problem of implementing variational methods, which is the need to consider complex problems of nonlinear programming. The basic and most famous of such equations $[6,7]$ are the first-order operator equations.

Finding effective iterative processes for getting an approximate solution is a difficult task for them. The nonlinear integral equations used in [1,3] are the second-order operator equations. They allow to take into account the roughness of the surfaces of interacting bodies. Such equations can be used to develop an efficient numerical algorithm for solving contact problems based on the construction of converging iterative processes. 
The algorithm is based on reducing the problem to a nonlinear integral equation, discretizing it, and using a converging iterative process to obtain a solution of the sampled equation. The roughness was taken into account by introducing into the expressions of the relative elastic displacements of interacting bodies of nonlinear additives characterizing the displacement of surface microirregularities.

The purpose of this article is to develop such an algorithm and use it to solve the spatial axisymmetric problem of pressing a close to flat stamp with rounded edges into an elastic rough half-space.

In this problem, the roughness was taken into account by means of the degree law of deformation of microirregulities [5].

The distribution of normal contact stresses, the dependence of the radius of the contact plane and the maximum pressure on the load are analyzed.

The analysis of the obtained results shows that taking into account the surface roughness in the problem of pressing a stamp close to flat with rounded edges into an elastic rough half-space can lead to a noticeable increase in the size of the contact zone and to a significant change in the distribution of contact pressure.

\section{REFERENCES}

1. Alexandrov A.I. Solution of problems of contact interaction of elastic bodies using nonlinear operator equations. Dnepropetrovsk: Institute of Technical Mechanics, Academy of Sciences of the USSR, 1989. 74 p. (Preprint / Academy of Sciences of the USSR, Institute of Technical Mechanics; 89-2). (in Russian).

2. Alexandrov A.I. Problems of the existence of solutions of some nonlinear integral equations. Dnepropetrovsk: DSU, 1991. 48 p. (in Russian).

3. Alexandrov A.I., Grabko O.V. Theorems of the existence of a solution for a contact problem on the interaction of elastic bodies having rough surfaces // ZNU Bulletin. Ser.: Physical and mathematical sciences. 2010. No 1. P. 11-17. (in Russian).

4. Alexandrov A.I., Grabko O.V. An algorithm for the numerical solution of a spatial contact problem on the interaction of elastic bodies having rough surfaces // Problems of Computational Mechanics and Strength of Structures. 2011. Vol.17. P. 23-34. (in Russian).

5. Alexandrov V.M., Pozharskii D.A. Three-dimensional contact problems in the account of friction and nonlinear roughness // Applied Mathematics and Mechanics. 2004. Vol. 68. Issue 3. P. 516-527. (in Russian).

6. Galanov B.A. A method of boundary equations of the Hammerstein kind for contact problems of linear elasticity in case unknown contact areas // Applied Mathematics and Mechanics. 1985. Vol. 49. Issue 5. P. 827-835. (in Russian).

7. Galanov B.A. Nonlinear boundary equations of contact problems of elasticity theory // Dokl. USSR Academy of Sciences. 1987. Vol. 296. No 4. P. 812-815. (in Russian).

8. Grabko O.V. Accounting surfaces roughness in contact problem of elastic spheres // ZNU Bulletin. Physical and mathematical sciences. 2011. No 1. P. 14-18.(in Ukrainian).

9. Kantorovich L.V., Akilov G.P. Functional analysis. Moscow: Nauka, 1984. 752 p. (in Russian).

10. Kozachok O.P., Martynyak R.M., Slobodian B.S., Interaction between bodies with regular relief in the presence of an interstitial medium. Lviv: Rastr-7, 2018. 200 p. (in Ukrainian). 
11. Tkachuk N.N., Skripchenko N.B., Tkachuk N.A., Grabovsky A.V. Contact interaction of complex-shaped details of engineering structures with local compliance of the surface layer. Kharkov: FOP Panov A.N., 2017. 148 p. (in Russian).

12. Tkachuk N.N., Tkachuk N.A. Contact of the complex bodies: linked task of analysis of the tensely-deformed state and geometrical synthesis // Mechanics and machine blowing. 2011. No2. P. 75-86. (in Russian).

13. Goryacheva I.G., Martynyak R.M. Contact problems for textured surfaces involving frictional effects // Proceedings of the Institution of Mechanical Engineers, Part J: Journal of Engineering Tribology. 2014. Vol. 228. No 7. P. 707-716.

14. Goryachev I.G., Malanchuk N.I., Martynyak R.M. Contact interaction of bodies with a periodic relief during partial slip // Journal of Applied Mathematics and Mechanics. 2012. Vol. 76. No 5. P. 621-630.

Друкується за рекомендацією програмного комітету IX Міжнародної науковотехнічної конференції «Актуальні проблеми прикладної механіки та міцності конструкцій», Online 11-14 червня 2020 р. м. Запоріжжя.

${ }^{1}$ /нститут прикладних проблем

механіки і математики

ім. Я.С. Підстригача НАН України,

Львів,

Україна

${ }^{2}$ Запорізький металургійний коледж

Запорізького національного університету,

Запоріжжя,

Україна

Надійшло до редколегї̈ 14.05.2020 